\title{
The Monterey event in the Mediterranean: A record from shelf sediments of Malta
}

\author{
Elizabeth Jacobs, Helmut Weissert, and Graham Shields \\ Geological Institute, Swiss Federal Institute of Technology, Zürich, Switzerland \\ Peter Stille \\ C.N.R.S., Centre de Géochemie de la Surface, Strasbourg, France
}

\begin{abstract}
Oligo-Miocene carbonate platform and shelf sediments outcropping on the Maltese Islands provide an excellent archive of the paleoceanography of the central Mediterranean. A sequence of shallow water limestones, than shelf limestones, and marls, followed again by shallow water limestones, reflects drowning of a carbonate platform, the establishment of a shelf environment and, in the late Miocene, renewed progradation and aggradation of shallow water carbonates. The sequence recording the deepening of the Maltese platform contains several phosphorite hardgrounds and phosphorite pebble beds. These phosphorites were dated with strontium isotopes. Major episodes of phosphogenesis occurred between 25 and $16 \mathrm{Ma}$, and they are coeval with those phosphorite events reported from Florida and North Carolina. A Miocene carbon isotope and oxygen isotope stratigraphy was established on planktic and benthic foraminifera and on bulk samples. A major carbon isotope excursion with an amplitude of up to $+1 \%$ between 18 and $12.5 \mathrm{Ma}$ can be correlated with the globally recognized Monterey carbon isotope excursion. This is the first record of this event both in shallow water sediments and in the Mediterranean. The carbon isotope excursion precedes an oxygen isotope excursion which also was recognized in deep-sea records. Major episodes of phosphogenesis and platform drowning preceded the carbon isotope excursion by up to millions of years.
\end{abstract}

\section{Introduction}

The early-middle Miocene is marked by an excursion in the marine $\delta^{13} \mathrm{C}$ record. This $\mathrm{C}$-isotope event is documented in planktic and benthic foraminifera as well as in bulk carbonate carbon isotope records from the Pacific, Atlantic, and Indian Oceans. It is interpreted as an indicator of a major perturbation of the global carbon cycle [Vincent and Berger, 1985; Woodruff and Savin, 1989; Hodell, 1991; Woodruff and Savin, 1991; Hodell and Woodruff. 1994]. Fluctuations in the global $\delta^{13} \mathrm{C}$ record are commonly interpreted as indicators of changing $\mathrm{C}_{\text {organic }} / \mathrm{C}_{\text {carbonate }}$ burial rates. Vincent and Berger [1985] recognized a link between carbon isotope stratigraphy, organic carbon burial, and phosphogenesis in the Monterey Formation. They explained carbon isotope excursions with changes in upwelling which lead to an increase in organic carbon production and $\mathrm{C}_{\text {organic }}$ burial. Increased burial of carbon dioxide fixed in organic matter resulted in global cooling. Their Monterey hypothesis has been disputed by Hodell and Woodruff [1994] and Raymo [1994]. These authors provide a different explanation for the middle Miocene cooling. They postulated that increased silicate weathering

Copyright 1996 by the American Geophysical Union.

Paper number 96PA02230.

0883-8305/96/96PA-02230\$12.00 related to mountain building resulted in increased $\mathrm{CO}_{2}$ drawdown. They suggested that increased organic carbon burial may have resulted from elevated nutrient supply by river action.

With this study we contribute to the running debate about the possible links between climate, the phosphorus cycle, and the carbon cycle in the Miocene. The Miocene shelf carbonates outcropping on the Maltese Islands offer the opportunity to reconstruct the response of the Mediterranean to changes in Miocene climate and oceanography. We used planktic and benthic foraminifera and bulk carbonate for the establishment of a central Mediterranean $\delta^{13} \mathrm{C}$ and $\delta^{18} \mathrm{O}$ record. We also determined Sr-isotopic compositions of carbonates and phosphate peloids in order to date the episodes of phosphogenesis and to correlate them with other phosphate deposits of the world. The Maltese shelf sequences further opened up the unique possibility to relate the $\delta^{13} \mathrm{C}$ record with the evolution of a Mediterranean carbonate shelf, with sea level, and with the Miocene carbonate platform drowning.

\section{Geographical and Stratigraphical Setting}

The Maltese Islands occupy a central position in the Mediterranean Sea (Figure 1). They are part of the north African continental margin characterized by thick Mesozoic Tertiary carbonates. Exposed are Oligo-Miocene limestones 


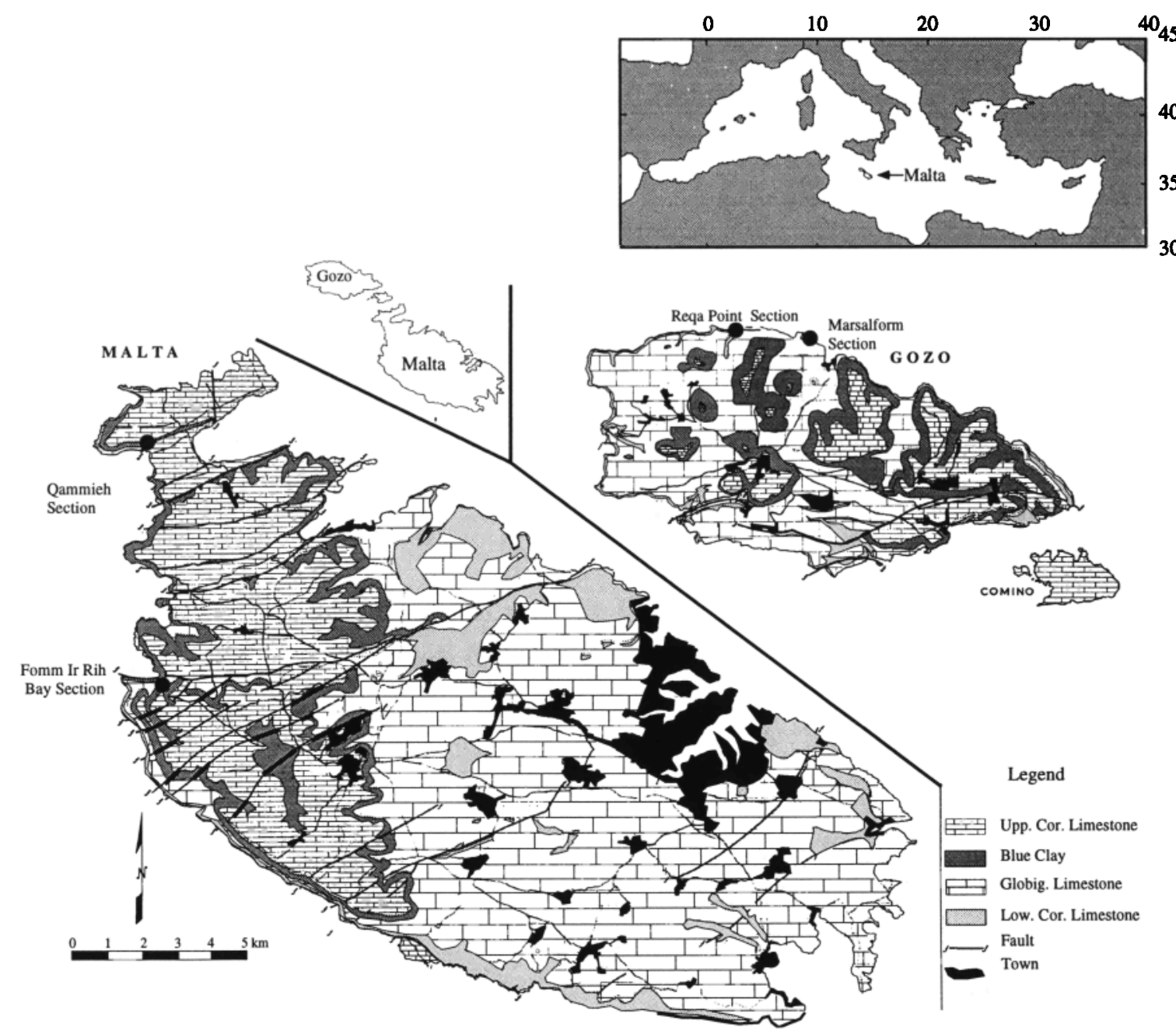

Figure 1. Geographical and geological map of the study area [modified after Felix, 1973]. Solid circles indicate locations of the studied sections.

and marls overlain by continental Quaternary deposits. The Tertiary marine sedimentary sequences of Malta and Gozo are divided into five formations: (1) Lower Coralline Limestone Formation, (2) Globigerina Limestone Formation, (3) Blue Clay Formation, (4) Greensand Formation, and (5) Upper Coralline Limestone Formation [Felix, 1973]. Despite extensional faulting, these units have more or less retained their original horizontal bedding. The sediments were deposited under relatively shallow water conditions on a shelf extending from Malta to Sicily known as "Ragusa platform" [Pedley et al., 1976]. Water depth in the early Miocene was only a few meters to a few tens of meters, while the sediments of middle Miocene (Langhian-Serravallian) age were deposited at a depth of up to $150-200 \mathrm{~m}$. Very shallow depositional conditions were reestablished in the late Miocene.

\section{Stratigraphy and Sedimentology}

The Lower Coralline Limestone forms the base of the sections investigated in Malta and Gozo. It reaches a maximum thickness of about $140 \mathrm{~m}$. The formation is composed mainly of massive limestone beds of shallow marine origin, generally composed of skeletal remains of calcareous algae, benthic foraminifera, corals, bryozoans, brachiopods, serpulids, molluscs, and echinoderms. The formation consists in its lower part of up to $100 \mathrm{~m}$ of a yellow, packed biomicrite rich in benthic foraminifera. A pale gray, cross-bedded coralline algal limestone rich in Lithothamium and Archaeolithothamnium conformably overlies the biomicrites. In eastern Malta, this upper member is replaced by fine-grained biosparites and biomicrites containing a rich foraminiferal fauna of Lepidocyclina dilatata and Heterostegina. Several horizons with a rich scutella fauna mark the top of the formation. The overlying Globigerina limestone consists of a sequence of micritic limestones and marls which may be subdivided into three members: lower, middle, and upper Globigerina limestone [Felix, 1973]. These members are separated by two phosphatic nodule beds [Pedley, 1975b; Pedley and Bennett, 1985]. The lower Globigerina limestone is a yellow to cream, massive bedded, globigerinid biomicrite. Selective cementation of burrows, together with preferential erosion of the surrounding softer sediment, is responsible for the characteristic honeycomb weathering of the unit. The upper 
limit of the lower Globigerina limestone is defined by a phosphorite hardground which caps the unit. The fossil content of this phosphorite bed consists of molluscs and clasts, together with sharks teeth. The infauna is restricted to Chlamys and the echinoids Euparagus and Spatangus [Roman and Roger, 1939; Zammit-Maempel, 1969; Rose, 1975].

The middle Globigerina limestone reaches a thickness of about $16 \mathrm{~m}$. It consists of white and pale gray marls and biomicrites. Fossils include echinoids ( $S$. parkinsoni, $S$. europhytus) and bivalves (Chlamys and Flabellipecten). Thalassinoides burrow systems are also prominent. At the top of this member, an "upper phosphorite conglomerate bed" is well exposed throughout Malta and Gozo; it consists of about $0.5 \mathrm{~m}$ of phosphorite pebbles with additional reworked, phosphatized clasts including the solitary coral Flabellum. The upper Globigerina limestone is about $19 \mathrm{~m}$ thick; the foraminiferal biomicrites are subdivided into three stratal packages by two phosphorite pebble layers. The macrofauna is sparse and generally restricted to occasional pectinid valves, the echinoid Schizaster, and the gastropod Epitonium [Pedley. 1975a, 1976].

A distinct change from limestone to marl with a low carbonate content of $20 \%$ marks the boundary between the Globigerina Limestone and the Blue Clay Formation. The Blue Clay Formation varies in thickness between some decimeters and up to about $60 \mathrm{~m}$ [Felix, 1973]. The fossil content of the Blue Clay includes gastropods (Conus and Strombus); the upper part is particularly rich in planktic and benthic foraminifera. Clay mineralogy of the Globigerina Limestone and Blue Clay Formations was carried out by Visser [1991]. The Blue Clay Formation has a higher kaolinite, chlorite, and illite to smectite ratio than the Globigerina Limestone Formation. A level rich in palygorskite marks the boundary between these two formations. The top of the Blue Clay Formation is characterized by an increase in glauconite.

The overlying Greensand Formation is up to $12 \mathrm{~m}$ thick, and it consists of a basal clayey part and upper calcareous sequence. The calcareous sequence is composed of a poorly cemented bioclastic and glauconitic limestone. In this facies, large echinoids are present and Heterostegina is abundant.

The Upper Coralline Limestone is the youngest Miocene formation. It resembles the Lower Coralline Limestone. The maximum preserved thickness of this unit is about $27 \mathrm{~m}$. A large coralline algal biostrome is well exposed in western Malta and eastern Gozo and occurs at the base of the formation. In other areas the lower part of the Upper Coralline Limestone consists entirely of algal rhodoliths, with thin intercalated layers and lenses of algal debris with echinids and Pecten.

The presence of Miliolidae and Peneroplidae observed in the Lower Coralline Limestone Formation indicates a shallow water back reef environment, with water depths not exceeding $30-50 \mathrm{~m}$. The Globigerina Limestone Formation is interpreted as a transgressive facies and, thus represents a deepening of the former carbonate platform. Benthic assemblages in the lower part of the Globigerina Limestone Formation such as Nonion boueanum [Blanc-Vernet, 1969], which seems to thrive in muddy to finely clastic sediments, indicate water depths between 30 and 70 meters. In the upper part of the Globigerina Limestone Formation the benthic fauna show a trend to a more muddy seawater bottom. This trend continues into the Blue
Clay Formation. In the Blue Clay Formation the increase of many benthic foraminifera such as buliminids indicates more open-marine conditions, although buliminid species Bulimina ovata and $B$. inflata have been reported from different sequences at water depths of less than $200 \mathrm{~m}$. The abundance of macrofaunal species Flabellipecten larteti and Genota spp., also suggests water depths of the order of $150 \mathrm{~m}$. A renewed shallowing in the Maltese sections is marked by the onset of conditions which lead to the deposition of the Greensand Formation. The appearance of Heterostegina indicates water depths of less than 70 meters. The renewed shallowing trend continued into the Upper Coralline Limestone Formation. This formation represents a carbonate platform growing in water depths of less than $50 \mathrm{~m}$ with calcareous algae and epibenthic foraminifera (Cibicides lobulatus). This facies interpretation (Figure 2) agrees with observations made by Felix [1973], Bennett [1979] and Pedley and Bennett [1985].

\section{Methods}

\section{Biostratigraphy}

The biostratigraphy and chronostratigraphy of the Miocene sequence of the Maltese Islands defined in this study are based mainly on planktic foraminifera and on calcareous nannofossils. On the basis of the zonal scheme of Blow [1969] the sediments studied were assigned to the following stages: Aquitanian, Burdigalian, Langhian, Serravallian, and Tortonian (Figure 2). With calcareous nannofossils we identified a Chattian age at the base of the section (lower Globigerina limestone; NP 25). According to the nannofossil biozonation of Martini [1971] the Greensand Formation belongs to the biozone (NN6-7; Figure 2).

\section{Sr Isotope Stratigraphy}

For Sr-isotope measurements we selected only pure peloidal phosphate grains originating from the major phosphorous horizons on the Maltese Islands. From previous studies we know that these authigenic peloids may be perfectly suited for Sr-isotope stratigraphy [McArthur et al., 1990; DePaolo and Ingram, 1985; Compton et al., 1993; Stille et al., 1994]. Peloids commonly have greater mineralogical uniformity and chemical stability than other phosphate material such as phosphatic brachiopods, fish vertebrae, and bone splinters [Riggs et al., 1996]. After hand-picking the peloids to $99 \%$ clean under a binocular microscope, they were washed in $20-100 \%$ pure acetic acid. This treatment is intended to remove any Sr-rich calcite overgrowths and did not attack the phosphate itself. After two acid treatments the peloids were individually cleaned in ultrapure water and rubbed free of extraneous material using gloves. One peloid was then chosen for each sample and reacted with $<1 \%$ HCL "suprapur" in a centrifuge tube for less than $10 \mathrm{~min}$ and centrifuged. The leachate was allowed to evaporate overnight, with subsequent concentration of strontium carried out using standard cation-exchange procedures.

Calcitic samples (pecten, brachiopod, and foraminifera shells) were first washed in dilute acetic acid before being dissolved completely in $<5 \%$ pure acetic acid for no longer than $10 \mathrm{~min}$, before centrifugation and evaporation of the leachate. 


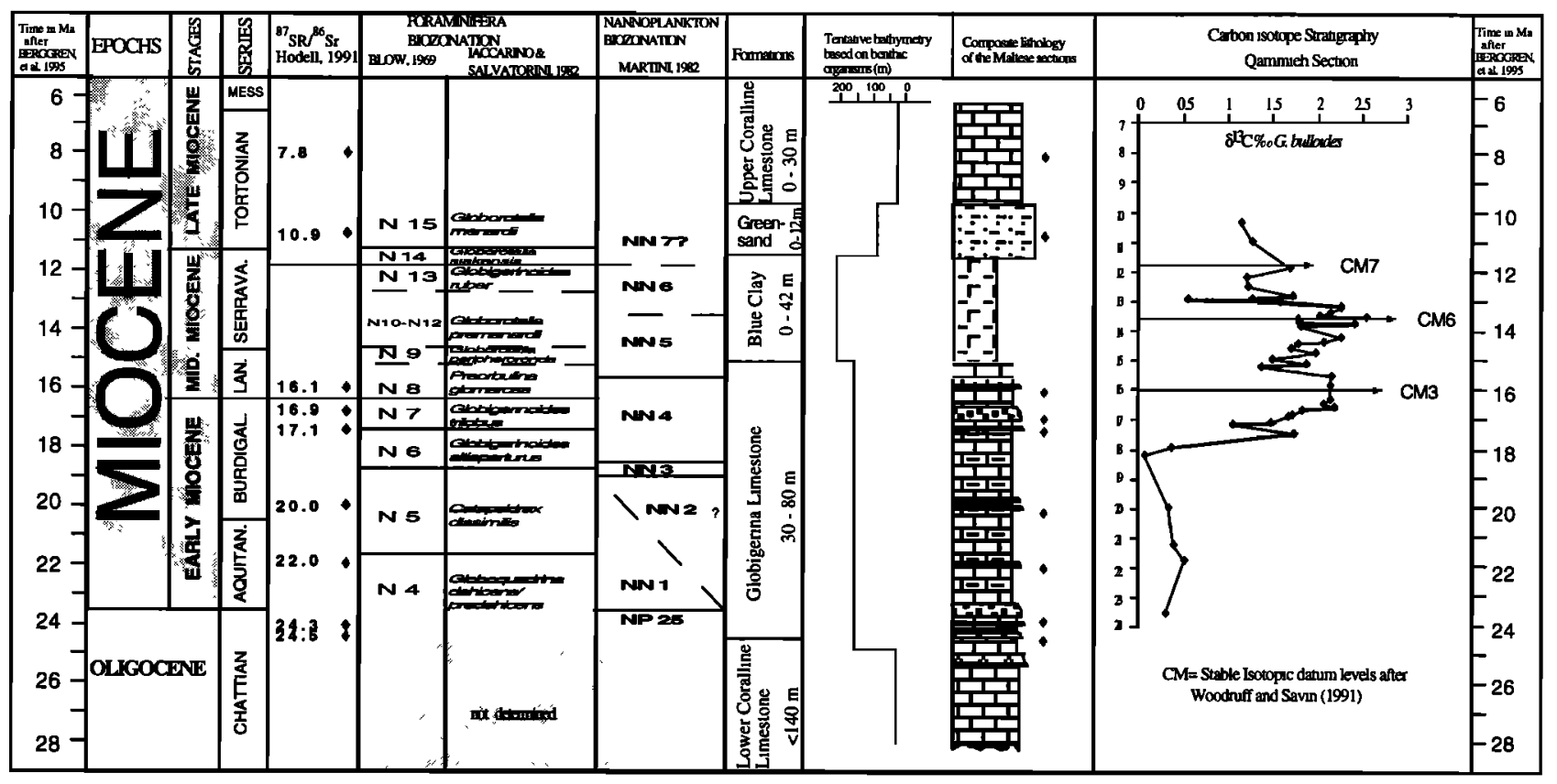

Figure 2. Composite lithostratigraphy and chronostratigraphy of the Maltese sediments based on strontium isotope data, biostratigraphy of planktic foraminifera and calcareous nannofossils and carbon isotope stratigraphy. The bathymetrical interpretation is based on benthic organisms. Strontium isotope samples (denoted by solid diamonds) from 24 to $20 \mathrm{Ma}$ are from the Fomm Ir Rih section (Figure 1) and from 17 to 7 $\mathrm{Ma}$ are from the Qammieh section. An additional sample with an age of 16.1 Ma from the Fomm Ir Rih Bay section is plotted (see Figure 1 for location). Strontium ages are cited to the first decimal place only, and errors on these ages can be rounded up to $\pm 0.8 \mathrm{Ma}(24-16 . \mathrm{Ma})$ and $\pm 1.4 \mathrm{Ma}(16-8 \mathrm{Ma})$, respectively.

Sr-isotope analysis was carried out at the Centre de Géochimie de la Surface (CGS/CNRS) in Strasbourg, France, using the techniques described by Stille et al. [1994] and at the Institute of Isotope Geology and Mineral Resources, Eidgenosissche Technische Hochschule Zürich, Switzerland [see Fischer, 1988]. At the time the isotope analysis was performed, the NBS 987 standard yielded a ${ }^{87} \mathrm{Sr} /{ }^{86} \mathrm{Sr}$ value of $0.710269 \pm 5$ (2 $\sigma$ mean, $n=15)$ at the CGS and $0.710245 \pm 7(2 \sigma$ mean, $n=13$;) at the ETH.

\section{Carbon and Oxygen Isotope Stratigraphy}

Samples for the stable isotope investigation were selected from the Globigerina limestone, from the Blue Clay Formation, and from the Greensand Formation. Sediment samples were desegregated, washed over $315-$ and $125-\mu \mathrm{m}$ sieves, and oven dried at $105^{\circ} \mathrm{C}$. Pristine specimens of benthic and planktonic foraminifera, common throughout the sequence, were handpicked for carbon and oxygen isotope analysis. Specimens with organic or pyritic fillings or exhibiting phosphatization were discarded. For control purposes, scanning electron microscope photographs were taken and showed no evidence of recrystallization. Approximately 15-20 specimens of planktic and 7-10 specimens of benthic foraminifera representing 250-315 $\mu \mathrm{g}$ of carbonate were required for each measurement. Foraminifera were cleaned in methanol, dried, roasted at $375^{\circ} \mathrm{C}$ to remove organic contaminants, and reacted in phosphoric acid at $90^{\circ} \mathrm{C}$ with an on-line-automated carbonate $\mathrm{CO}_{2}$ preparation device; the evolved $\mathrm{CO}_{2}$ was cryogenically distilled to remove water produced during the reaction. Samples were run on a VG precision isotope ratio mass spectrometer (PRISM) at the Geologisches Institut ETH, Zürich. Instrumental precision for these analyses of the laboratory standard, Carrara marble (MS-2), was $\pm 0.07 \%$ for $\delta^{18} \mathrm{O}$ and $\pm 0.03 \%$ for $\delta^{13} \mathrm{C}$. Replicate analyses on about one fourth of the samples demonstrated a reproducibility of $\pm 0.04 \%$ o for $\delta^{18} \mathrm{O}$ and $\pm 0.02 \%$ for $\delta^{13} \mathrm{C}$. The results ${ }^{1}$ are reported relative to the Pee Dee belemnite (PDB) standard (Figures 36).

\section{Results}

\section{Strontium Isotope Data}

The data are compiled in Table 1. In order to compare our data directly with the seawater curve of Hodell [1991] we normalized our data to their measured NBS $987{ }^{87} \mathrm{Sr} /{ }^{86} \mathrm{Sr}$ isotopic composition value of 0.710235 . The resulting ${ }^{87} \mathrm{Sr} /{ }^{86} \mathrm{Sr}$ values range between 0.7082 and 0.7089 (Table 1). The corresponding ages were calculated using their isotopic composition values and regression equations for the ${ }^{87} \mathrm{Sr} /{ }^{86} \mathrm{Sr}$ isotopic composition of seawater as a function of age developed by Hodell [1991]. The resolution of strontium isotopic stratigraphy for a given time period is largely dependent upon the rate of ${ }^{87} \mathrm{Sr} /{ }^{86} \mathrm{Sr}$ increase relative to

\footnotetext{
'Supporting isotope data are available via Anonymous FTP from Kosmos.agu.org, directory APEND (Username = anonymous, Password = guest). Diskette may be ordered from American Geophysical Union, 2000 Florida Avenue, N. W., Washington, DC 20009 or by phone at 800-966-2481; $\$ 15.00$. Payment must accompany order.
} 


\section{Qammieh section}

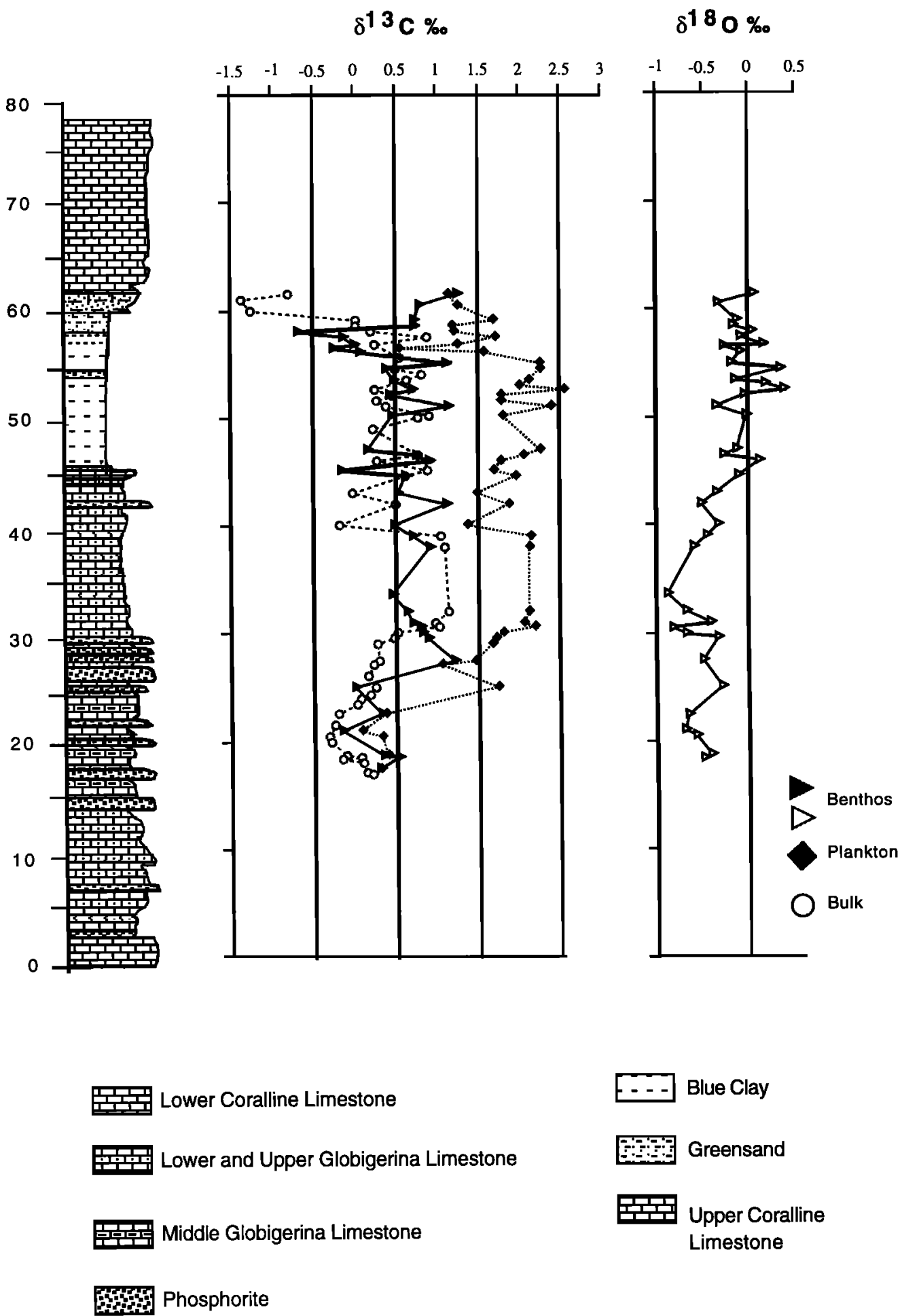

Figure 3. Carbon and oxygen isotopic record of the early and middle Miocene from the Qammieh section, NW Malta. The Monterey carbon isotope excursion is clearly expressed between 20 and $60 \mathrm{~m}$. Open circles denote $\delta^{13} \mathrm{C}$ of bulk carbonate, solid squares denote $\delta^{13} \mathrm{C}$ of Globigerinoides bulloides, and triangles denote $\delta^{13} \mathrm{C}$ and $\delta^{18} \mathrm{O}$ of Cibicidoides spp. 
Qammieh Section

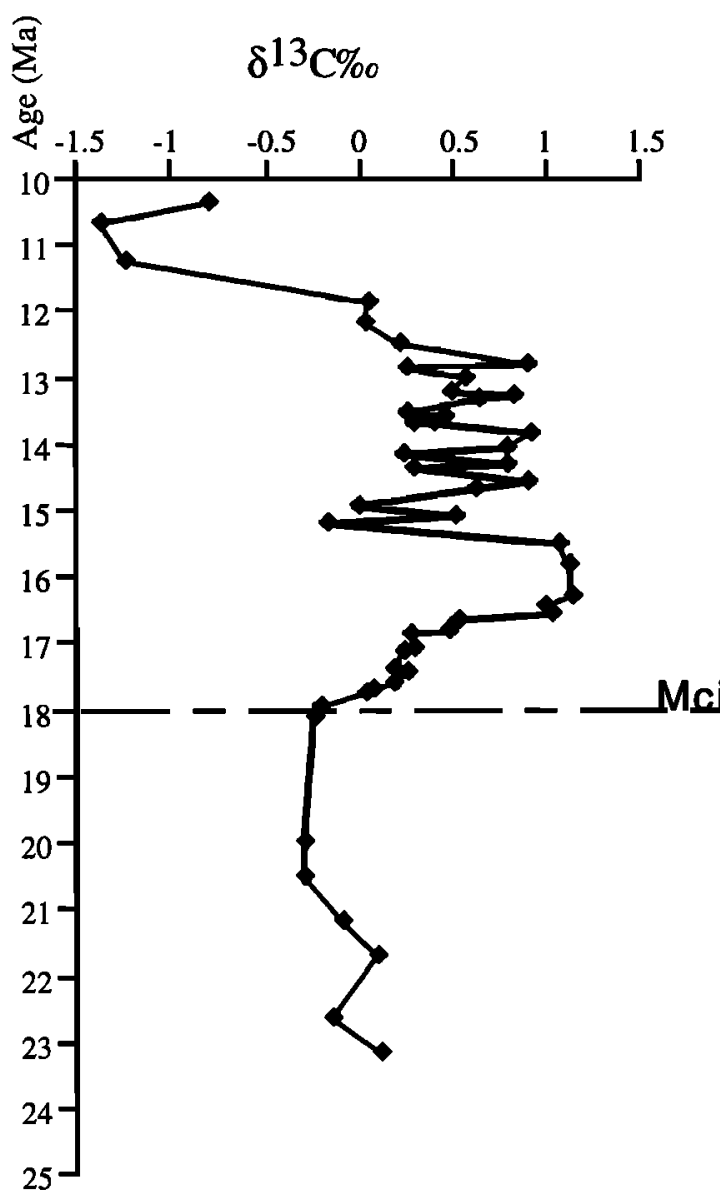

Fomm Ir Rih Bay Section

$$
\delta^{13} \mathrm{C} \%
$$

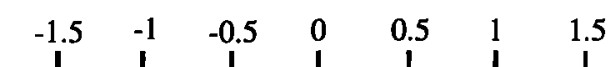

Figure 4. Bulk carbonate carbon isotope record versus age from Qammieh and Fomm Ir Rih Bay sections. The initiation of the Monterey carbon isotope excursion is marked with the dashed line.

analytical error. Using the regression analysis of Hodell [1991] the following errors of the $\mathrm{Sr}$ age dates have to be considered at the $95 \%$ confidence interval: $\pm 0.74 \mathrm{Ma}$ and $\pm 1.36 \mathrm{Ma}$ for the age ranges of 24.0-16 $\mathrm{Ma}$ and 16.0-8.0 Ma, respectively. The $\mathrm{Sr}$ ages of the phosphate peloids and carbonates are in perfect agreement with the available biostratigraphic ages. This indicates not only that the samples are well preserved but also that the Mediterranean Sea and the oceans were well mixed with respect to Sr-isotopes during this time. Two samples that gave older ages than expected are clearly reworked; they are also from a layer where only very small sparse and different colored peloids were present.

\section{Carbon and Oxygen Isotope Data}

The carbon isotopic compositions of the planktic foraminifera Globigerinoides bulloides (Figures 3 and 5) fluctuate between $+0.2 \%$ and $+0.5 \%$ during the Aquitanian and early Burdigalian (N4 to N5, lower and middle Globigerina limestone), and increase from $+0.5 \%$ to $+2 \%$ in the Burdigalian at $18 \mathrm{Ma}$. From the middle Burdigalian to the middle Serravallian the $\delta^{13} \mathrm{C}$ values scatter around $+2 \%$. Within the Blue Clay Formation at about $12.5 \mathrm{Ma}$ the $\delta^{13} \mathrm{C}$ values decrease to $+0.5 \%$. At $13 \mathrm{Ma}$, during the upper
Serravallian, the $\delta^{13} \mathrm{C}$ compositions show an increase of almost $+1 \%$, which could represent the beginning of the late Miocene carbon isotope excursion.

In the sediments of Aquitanian age (lower Globigerina limestone) the carbon isotope composition of the benthic foraminifera Cibicidoides sp. (Figures 3 and 5) varies between $0 \%$ and $+0.5 \%$. In the Burdigalian, at $18 \mathrm{Ma}$ the $\delta^{13} \mathrm{C}$ values increase from $-0.3 \%$ to $+1.3 \%$. This shift toward more positive values is synchronous with the shift recognized in the planktic foraminifera curve. Relatively positive values persist throughout the Burdigalian, Langhian, and part of the Serravallian. During the Serravallian the $\delta^{13} \mathrm{C}$ values decrease again from $+1.2 \%$ to $-0.3 \%$.

At the Burdigalian-Langhian boundary, well preserved foraminifera are rare. This was the reason why the bulk carbonate of the same sections was measured in order to confirm the observed increase of the $\delta^{13} \mathrm{C}$ values. In the bulk carbonate curve (Figures 3 and 4 ) the same $+1.5 \%$ carbon isotope shift was recognized as was in the planktic and benthic foraminifera curve.

The oxygen isotopic composition of the planktic foraminifera Globigerinoides bulloides scatters between $-0.5 \%$ and $-2 \%$ in the lower part of the Globigerina limestone (Burdigalian), with no clear trend. From the Burdigalian to the 

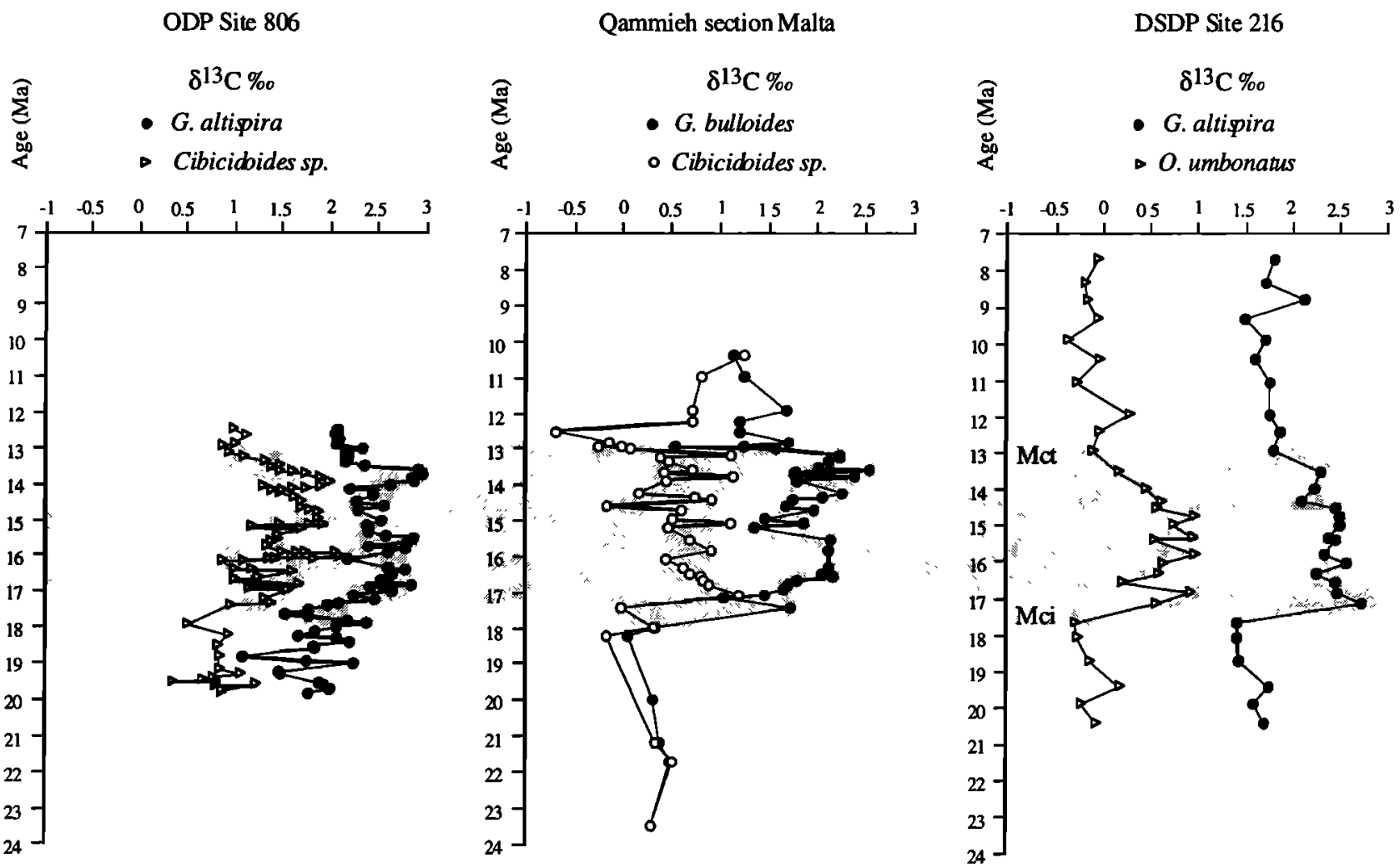

Figure 5. Early and middle Miocene $\delta^{13} \mathrm{C}$ record of planktic and benthic foraminifera versus age from southwest Pacific (ODP Site 806 [Corfield and Cartlidge, 1993]; solid circles denote $\delta^{13} \mathrm{C}$ of $G$. altispira and open triangles denote $\delta^{13} \mathrm{C}$ of Cibicidoides sp.); Malta (solid circles denote $\delta^{13} \mathrm{C}$ of $G$. bulloides and open circles denote $\delta^{13} \mathrm{C}$ of Cibicoides sp.); and the tropical Indian Ocean (DSDP Site 216 [Vincent and Berger, 1985]; solid circles denote $\delta^{13} \mathrm{C}$ of $G$. altispira and open triangles denote $\delta^{13} \mathrm{C}$ of $O$. umbonatus). Results are reported relative to the PDB standard. The shaded interval represents the initiation (Mci) and termination (Mct) of the Monterey carbon isotope excursion.

lower part of the Serravallian the $\delta^{18} \mathrm{O}$ values scatter around $-1.5 \%$. In the lower part of the Serravallian the oxygen isotopic composition decreases to $-2.5 \%$. Then the composition increases from $-2.5 \%$ to $-1 \%$ during the middle and upper Serravallian. At $13 \mathrm{Ma}$ the $\delta^{18} \mathrm{O}$ values show a decrease from $-1 \%$ o to $-2.5 \%$ before they increase again from $-2.5 \%$ to $-0.5 \%$ o in the lower part of the Tortonian.

Between 22 and $17 \mathrm{Ma}$ the oxygen isotopic composition of the benthic foraminifera Cibicidoides sp. (Figure 6) scatters between $-0.6 \%$ and $-0.3 \%$. At $17 \mathrm{Ma}$ the $\delta^{18} \mathrm{O}$ values decrease to $-\mathbf{0 . 8 \% o}$. Starting at $16 \mathrm{Ma}$, the $\delta^{18} \mathrm{O}$ values increase gradually from $-0.8 \%$ o to $+0.3 \%$ within the lower part of the Blue Clay Formation. This shift represents the initiation of the middle Miocene cooling step associated with the Antarctic ice build up [ Woodruff and Savin, 1989].

The bulk carbonate of the Qammieh section shows a pronounced shift in the $\delta^{18} \mathrm{O}$ values from $-1.8 \%$ to $+0.5 \%$ at about $23 \mathrm{Ma}$ and then a sharp decrease to $-1.5 \%$ in the lower part of the Globigerina limestone. At $18 \mathrm{Ma}$ the $\delta^{18} \mathrm{O}$ values increase gradually from $-1.3 \%$ to $+0.2 \%$ within the Blue Clay Formation and decrease again from $+0.2 \%$ to $-1 \%$ at $13 \mathrm{Ma}$.

\section{Discussion}

Our investigations of the Oligo-Miocene carbonate platform and shelf sediments on Malta allow us to draw a picture of the Miocene paleoceanography of the central Mediterranean. We are able to link it with changes in global carbon cycling and climate as recorded in carbon and oxygen isotope stratigraphies. Biostratigraphy, combined with Sr-isotope stratigraphy, provides an accurate time frame which facilitates the correlation of the Mediterranean record with platform and shelf sequences in other oceans and with Miocene deep-sea records.

The Malta sequence records a change from carbonate platform conditions to shelf environments in the Late Oligocene. The micritic foraminifera limestone facies of the Globigerina limestone was deposited on a deepening and episodically current swept shelf. Hardgrounds were formed during these episodes. Phosphorite crusts and pebbly phosphorite beds represent periods of no net sediment accumulation [Pedley and Bennett, 1985]. The present-day Peru margin [Burnett, 1977] with its phosphorite hardgrounds may 
ODP Site 806

$\sum_{\substack{0 \\ 0}}^{3}$

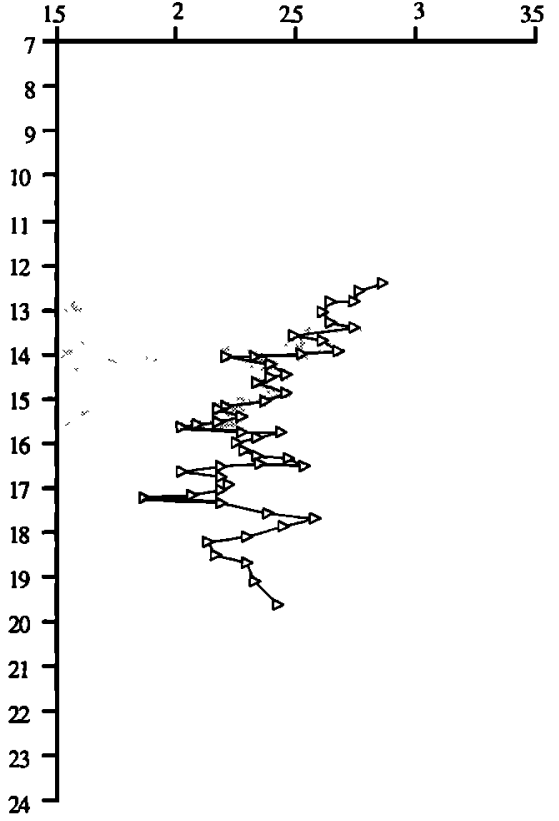

Qammieh section Malta

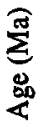

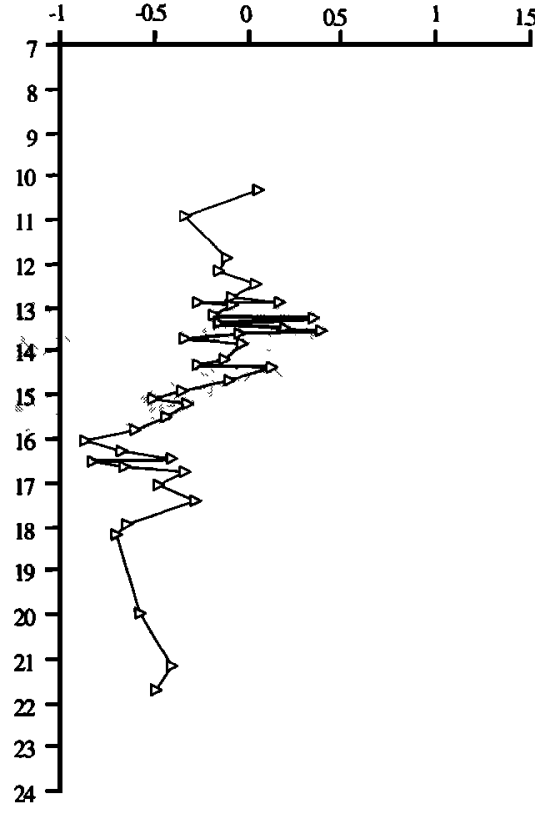

DSDP Site 216

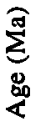

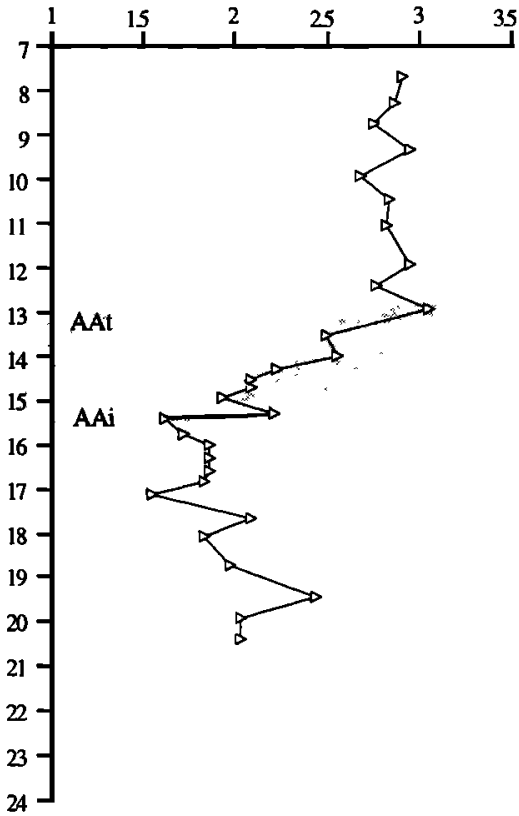

Figure 6. Early and middle Miocene $\delta^{18} \mathrm{O}$ record of benthic foraminifera versus age from southwest Pacific (ODP Site 806 [Corfield and Cartlidge, 1993], Malta, and the tropical Indian Ocean (DSDP Site 216 [Vincent and Berger, 1985]. Results are reported relative to the PDB standard. The shaded interval represents the initiation (AAi) and termination (AAt) of the Antarctic cooling episode.

serve as an actualistic example for the Miocene phosphorites which formed on the Malta-Ragusa shelf. The first major phosphorite bed, separating the lower from the middle Globigerina limestone, marks a distinct change in the benthic fauna, indicating a deepening of the Malta shelf. On the basis of these observations we conclude that the major phosphorite layers were formed at times of relative sea level rise and that platform drowning and successive deepening of the shelf occurred stepwise. The deepening upward trend recognized in the Globigerina Limestone Formation reached its maximum during the deposition of the Blue Clay Formation, which may have been deposited in a depth of up to $200 \mathrm{~m}$. The deepening of the shelf was accompanied by a change in carbonate content of the shelf sediments. Low carbonate contents of about $20 \%$ in the Blue Clay Formation seem to reflect a combination of increased dilution of the carbonate by detrital clay, decreased carbonate production, and increased dissolution of carbonate. The clay mineralogy of the Blue Clay Formation indicates a trend to more humid climate, resulting in intensified weathering, runoff, and transfer of fine siliciclastics into the central Mediterranean. If we combine the sedimentological information of the upper part of the Globigerina Limestone and Blue Clay Formations with the benthic $\mathrm{C}$-isotope signatures, we may conclude that an expanded oxygen minimum layer extended across the Malta shelf between 16 and $12 \mathrm{Ma}$. The shallow position of the oxygen minimum zone along the Peru margin could serve as an actualistic analog of the Malta situation [Burnett, 1977]. The deepening upward trend of the Malta shelf was reversed in the late Miocene. The Greensand and Upper Coralline Limestone Formations record a renewed shallowing upward of the Malta shelf and the reestablishment of carbonate platform conditions $12 \mathrm{Ma}$ after the inital drowning phase.

The sedimentological evolution of the Malta shelf shows remarkable analogies to the record of the western North Atlantic (Figure 7). The major episodes of phosphogenesis on the Malta shelf occurred between 24 and $16 \mathrm{Ma}$ and can be correlated with synchronous episodes of phosphogenesis along the western North Atlantic [Compton et al., 1990 and 1993; Stille et al., 1994]. In agreement with Compton et al., [1990], we consider a rise in sea level as one factor favoring the formation of phosphorite beds. Comparisons with Cretaceous records indicate that conditions for phosphogenesis were most favorable when specific paleoceanographic conditions coincided with times of accelerated weathering, erosion and transfer of nutrients from continents into oceans [e.g., Weissert, 1989; Föllmi et al., 1994; Raymo, 1994].

Increased nutrient loads had an impact not only on the marine phosphorus budget but also on the marine carbon system. The Miocene $\mathrm{C}$-isotope record shows how the rain rate of organic carbon to carbonate carbon was altered on a global scale beween 18 and $12 \mathrm{Ma}$. The C-isotope excursion, as we identified it in the Malta archives, started at $18 \mathrm{Ma}$. It reached its most positive values around $17 \mathrm{Ma}$, and it ended about 12.5 
Table $1 .{ }^{87} \mathrm{Sr} /{ }^{86} \mathrm{Sr}$ Measurements and Derived Ages of Samples From Malta

\begin{tabular}{|c|c|c|c|}
\hline Sample & $\begin{array}{c}{ }^{87} \mathrm{Sr} /{ }^{86} \mathrm{Sr} \\
\text { Mean Values a }\end{array}$ & $\begin{array}{c}{ }^{87} \mathrm{Sr} /{ }^{86} \mathrm{Sr} \\
\text { of Hodell }[1991]^{b}\end{array}$ & Age, ${ }^{c} \mathrm{Ma}$ \\
\hline \multicolumn{4}{|c|}{ Qammieh Section } \\
\hline Qab $2^{d}(L C L)^{e}$ & $0.708254(14)$ & 0.708244 & 24.00 \\
\hline Qab 3 (GL) & $0.708245(6)$ & 0.708211 & 24.54 \\
\hline Qab 4 (GL) & $0.708276(7)$ & 0.708242 & 24.03 \\
\hline Qab 28 (GL) & 0.708692 & 0.708658 & 17.16 \\
\hline Qab 29 (GL) & $0.708682(7)$ & 0.708648 & $17.32^{f}$ \\
\hline Qab 30 (GL) & $0.708700(6)$ & 0.708666 & 17.03 \\
\hline Qab 31 (GL) & 0.708704 (7) & 0.708669 & 16.96 \\
\hline Qab 39 (GL) & $0.708253(7)$ & 0.708219 & $24.41^{f}$ \\
\hline Qabb 19g (BC) & 0.70885 (18) & 0.70884 & 10.87 \\
\hline $\mathrm{LCL}^{\mathrm{d}} \quad(\mathrm{LCL})$ & $0.708256(6)$ & 0.708222 & 24.36 \\
\hline $\mathrm{UCL}^{\mathrm{i}} \quad$ (UCL) & $0.708946(6)$ & 0.708912 & 7.81 \\
\hline \multicolumn{4}{|c|}{ Fomm Ir Rih Bay Section } \\
\hline FG 5 & $0.708246(6)$ & 0.708212 & 24.53 \\
\hline (GL) & 0.708254 (7) & 0.708220 & 24.39 \\
\hline FG 8 (GL) & 0.708260 (6) & 0.708226 & 24.30 \\
\hline FG 17 (GL) & $0.708400(6)$ & 0.708366 & 21.98 \\
\hline FG $20^{d}(G L)$ & 0.708496 (11) & 0.708486 & 20.00 \\
\hline FG 41 (GL) & $0.708697(8)$ & 0.708663 & 17.08 \\
\hline FG43 (GL) & $0.708754(6)$ & 0.708720 & 16.14 \\
\hline \multicolumn{4}{|c|}{ Reqa Point and Marsalform Sections } \\
\hline RP 14 (LCL) & $0.708290(7)$ & 0.708256 & 23.80 \\
\hline MAR $_{\text {bottom }}(\mathrm{GL})$ & 0.708676 (6) & 0.708642 & 17.42 \\
\hline $\mathrm{MAR}_{\text {top }}(\mathrm{GL})$ & 0.708689 (7) & 0.708655 & 17.20 \\
\hline MAR $0 \quad(G L)$ & 0.708277 & 0.708243 & 24.02 \\
\hline \multicolumn{4}{|c|}{ Il Gelmus Section } \\
\hline (GR) & $0.709036(7)$ & 0.709002 & 6.3 \\
\hline
\end{tabular}

Formation abbreviations are LCL, Lower Coralline Limestone; GL, Globigerina Limestone; BC, Blue Clay; GR, Greensand; UCL, Upper Coralline Limestone. Uncertainties in brackets of the $\mathrm{Sr}$ isotopic compositions are at the $2 \sigma$ mean level. ${ }^{a}$ NBS 987:0.710269 (Str) 0.710245 (ETH).

$b_{\text {NBS } 987: 0.710235 .}$

cAfter correction to Hodell's [1991] NBS 987.

dPectinids.

SSamples were measured at ETH, Zürich.

$f_{\text {Interpreted to be reworked phosphate peloids being particurlarly small and from levels }}$

where there are only sparse peloids.

goraminifera.

${ }_{\text {Two foram fractions were measured. }}$

i Brachiopod.

Ma. The synchroneity of the Malta C-1sotope excursion with pelagic $\mathrm{C}$-isotope records confirms the global extent of the Miocene Monterey event in C-isotope stratigraphy.

While the amplitude of planktic record is comparable with records from the Pacific and Indian Oceans, the benthic $\mathrm{C}$ isotope excursion is marked by a low amplitude change. We interpet this discrepancy with the peculiar environment of deposition of the Blite Clay Formation. At the time of globally most positive $\mathrm{C}$-isotope values, benthic foraminifera on the Malta shelf lived within an expanded oxygen minimum layer. An expanded oxygen minimum layer enriched with isotopically light $\mathrm{CO}_{2}$ would have resulted in a negative shift of the benthic $\mathrm{C}$-isotope signal. This negative shift may have partly compensated the globally recognized positive shift of mid-Miocene ocean water.

The $\mathrm{C}$-isotope excursion is commonly interpreted as an indicator of increased burial of organic carbon. Increased nutrient loads not only may have resulted in an intensification of the marine organic carbon pump, but they may also have had an impact on the marine carbonate carbon burial rate. Coastal regions and shelves affected by elevated nutrient loads may have experienced growth crises resulting in platform 

Babcock Deep Core
W-10761
Malta

Age (Ma)

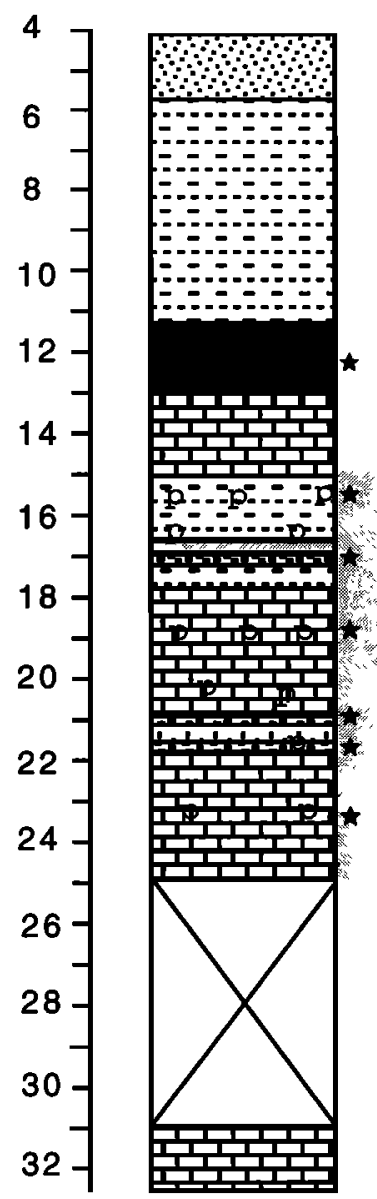

Formations

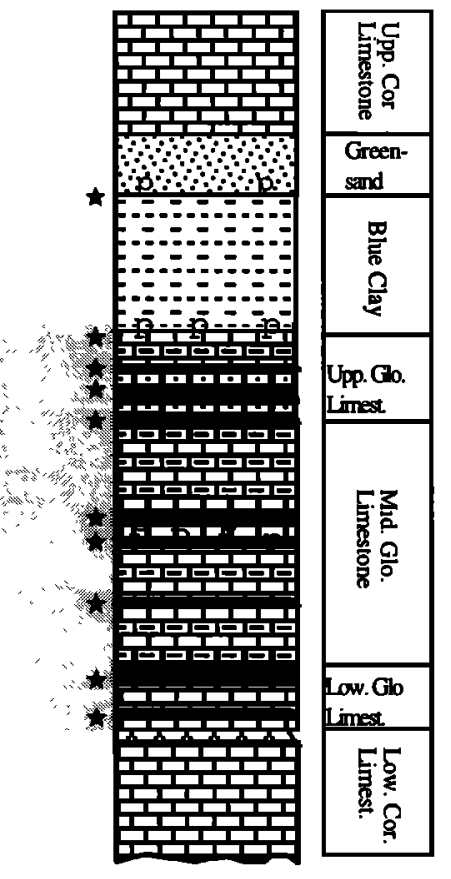

Legend:

臣 moldic limestone

조조정 Scutella bed

sand

E-:-ay clayilt

둠돌 marly limestone

Fring phosphorite/ pebbles

Fricrin sandy limestone

$P=\star$ phosphate - rich sediments

Figure 7. Comparison of major episodes of phosphogenesis with lithostratigraphy. Data are from the Babcock Deep Core South-Central Florida Platform [Compton et al., 1993]. The shaded interval represents major episodes of phosphogenesis between 25 and $15 \mathrm{Ma}$.

drowning and in regionally decreased carbonate sedimentation. This may explain why the increase in global organic carbon burial rates was not fully compensated by an equally large increase in carbonate carbon burial rate as reflected in the altered $\mathrm{C}_{\text {organic }} / \mathrm{C}_{\text {carbonate }}$ burial ratio. If we accept that growth crises of carbonate platforms during times of rising sea level may influence the carbonate carbon pump, then the $\mathrm{C}$ isotope excursion in the Miocene reflects a major perturbation of both marine carbon pumps. In this context it seems remarkable that the end of the Miocene $\mathrm{C}$-isotope excursion coincides with a shallowing upward trend of the Malta-Ragusa shelf. This reflects an improved growth potential of Mediterranean carbonate platforms in the late Miocene, and it could have contributed to the renewed decrease in $\mathrm{C}_{\text {organic/ }} \mathrm{C}_{\text {carbonate }}$ burial rate as reflected in decreasing $\delta^{13} \mathrm{C}$ values. An analogous link between carbonate carbon burial rates and the $\mathrm{C}$-isotope record has recently been suggested by Weissert and Mohr [1996] for the Late Jurassic and Early Cretaceous time intervals.

Variations in carbon burial rates had an impact on the atmospheric $\mathrm{CO}_{2}$ reservoirs, as discussed by Vincent and Berger [1985] for the Monterey event. The Malta sediments 
provide us with an oxygen istope curve which can be compared with the deep-sea records. The early Miocene (20-17 Ma) oxygen isotope curve shows minor fluctuations. This agrees with records from the Pacific and Atlantic Oceans (Figure 6). From 17 to $15.5 \mathrm{Ma}$ the oxygen isotopic composition of Malta shows a decrease of $0.5 \%$, indicating a phase of global warming. This decrease correlates with the one reported in Site 747 ranging from 17 to $15.5 \mathrm{Ma}$. Hodell and Woodruff [1994] attributed this decrease to the major eruption phase of the Columbia River Flood Basalt. After 15.5 Ma the $\delta^{18} \mathrm{O}$ curve shifts toward more positive values. The most positive $\delta^{18} \mathrm{O}$ values at $15 \mathrm{Ma}$ correlate with the maximum peak observed in the $\delta^{13} \mathrm{C}$ record. These $\delta^{18} \mathrm{O}$ values are interpreted to be the result of a middle Miocene cooling step associated with the Antarctic ice buildup [Woodruff and Savin, 1989]. If we compare the carbon isotope curve with the oxygen isotope record, we recognize a considerable time lag of up to 2 Ma between the initiation of the carbon isotope excursion and the shift in the oxygen isotope record to more positive values. This observation is in agreement with data from the Indian and Pacific Oceans [Vincent and Berger, 1985; Corfield and Cartlidge, 1993] and it may reflect a reduction in atmospheric $\mathrm{CO}_{2}$ levels due to increased global weathering and/or to an intensification of the marine carbon pumps [Hodell and Woodruff, 1994; Vincent and Berger, 1985; Raymo, 1994].

From 13 to $11 \mathrm{Ma}$ the $\delta^{18} \mathrm{O}$ values of Malta (Figure 6) show a gradual decrease by about $1 \%$, which is not observed in deep-sea sequences. This may be the local expression of the isolation of the Mediterranean Sea from the Indo-Pacifc Ocean. Today the Mediterranean Sea is a basin with an antiestuarine circulation (surface inflow with outflow at depth). The oxygen isotope record of different deep-sea sequences from the Atlantic, Indian, Pacific, and Southern Oceans show that deep water temperatures at $12.5 \mathrm{Ma}$ can be explained by deep water circulation changes. Wright and Miller [1992] argued that the Northern Component Water and Southern Component Intermediate Water were produced from 12.5 to 10 $\mathrm{Ma}$ and reflect an oceanic circulation pattern similar to today. Assuming that at $12.5 \mathrm{Ma}$ the Mediterranean Sea was closed from the Indian Ocean, an increasing influx of fresh water and changes in temperature and/or salinity may have produced a decrease in the oxygen isotopic composition of deep water as it is observed in the Maltese sections.

\section{Conclusions}

Miocene shallow water sediments outcropping on the Maltese Islands provide an excellent archive of Miocene paleoceanography. On the basis of sedimentological and paleontological evidence, we may conclude that the Miocene Malta-Ragusa platform experienced a stepwide deepening between 25 and $15 \mathrm{Ma}$. Phosphorite hardgrounds formed on the deepening shelf mark episodes of sea level rise. The Blue Clay Formation deposited between 15.5 and $12 \mathrm{Ma}$ and at a water depth near $200 \mathrm{~m}$ reflects the deepest conditions of the Malta shelf before a carbonate platform was reestablished at about 12 Ma. Using Sr-isotope stratigraphy, we are able to date major episodes of phosphogenesis between 24 and $17 \mathrm{Ma}$. These were coeval with analogous episodes of phosphogenesis on the Florida and North Carolina shelves. We have established a Miocene $\mathrm{C}$-isotope curve on planktic and benthic foraminifera and on bulk samples, and we can document how the major Montery C-isotope event followed the episodes of phosphogenesis with a lag of up to millions of years. The maximum of the $\mathrm{C}$-isotope excursion at $16 \mathrm{Ma}$ coincided with the deposition of the upper Globigerina limestone and Blue Clay Formation and with the onset of global mid-Miocene cooling as indicated in the $\mathrm{O}$-isotope record. The Mediterranean $\mathbf{O}$-isotope curve not only records changes in global climate, but a shift to isotopically lighter values also reflects the closure of the Mediterranean from the Indo-Pacific Ocean between 13 and $11 \mathrm{Ma}$.

Acknowledgments. The authors thank M. Pika-Biolzi and K. PerchNielsen (ETH Zürich) for biostratigraphic advice. I. Stössel, S. Bernasconi, and D. Bernoulli (ETH Zürich) provided very helpful criticism and comments, which are gratefully acknowledged. We acknowledge the continuous support of H. R. Thierstein (ETH Zürich) and B. Mohr (Museum für Naturkunde Berlin). Many thanks to $B$. Kiefel and D. Tisserand at the CGS/CNRS in Strasbourg for their invaluable help in the laboratory. We have especially appreciated the continued interest and help of G. Zammit-Maempel on all matters relating to the geology of the islands. Constructive reviews by $\mathrm{J}$. Compton, B. Garrison and L. Derry helped to improve the manuscript. This research was supported by the Swiss National Science Foundation grant NSF 20-36555.92.

\section{References}

Bennett, S.M., A transgressive carbonate sequence spanning the Paleogene-Neogene boundary on the Maltese Islands, Ann. Geol. Pays Hell., Tome horse ser. 1, 71-80, 1979.

Blanc-Vernet, L., Contribution à l'étude des foraminifères de la Méditerraée: Relations entre le microfaune et le sédiment: Biocoenoses actuelles, thanatocoenoses pliocènes et quaternaires, Rec. Trav. Strat. Mar. d'Etoume, 64, 281, 1969.

Blow, W.H., Late Middle Eocene to recent plankonic foraminiferal biostratigraphy, Proc. Int. Conf. Plank. Microfossils, $1,199-442,1969$.

Burnett, W.C., Geochemistry and origin of phosphorite deposits from Peru and Chile, Bull. Geol. Soc. Am., 88, 813-823, 1977

Compton, J., S.W., Snyder, and D., Hodell, Phosphogenesis and weathering shelf sediments from SE USA: Implications for Miocene $\delta^{13} \mathrm{C}$ excursion and global cooling, Geology, $18,1227-1230,1990$.

Compton, J.S., D.A., Hodell, J.R., Garrido, and D.J., Mallinson, Origin and age of phosphorite from the south-central Florida Platform: Relation of phosphogenesis to sea-level fluctuations and $\delta^{13} \mathrm{C}$ excursions, Geochim. Cosmchim. Acta., $57,131-146,1993$.

Corfield, R.M., and J.E., Cartlidge, Oxygen and carbon isotope stratigraphy of the middle Miocene, Holes 805B and 806B in Proc. Ocean Drill. Program, Sci. Res., 130, 307-322, 1993

DePaolo, D.J., and B.L., Ingram, High-resolution stratigraphy with strontium isotopes, Science, 227, 938-941, 1985.

Felix, R., Oligo-Miocene stratigraphy of Malta and Gozo, Ph.D. dissertation, Univ. of Utrecht, Utrecht, Netherlands, 1973.

Fischer, H., Isotopengeochemische Untersuchungen und Datierungen an Mineralien und Fossilien aus Sedimentgesteinen, Ph.D. dissertation, Eidgenossische Technische Hochschule Zürich, Switzerland, 1988.

Föllmi, K.B., H., Weissert, M., Bisping, and H., Funk, Phosphogenesis, carbon-isotope stratigraphy, and carbonateplatform evolution along the Lower Cretaceous northern Tethyan margin, Bull., Geol. Soc. Am., 106, 729-746, 1994.

Hodell, D. A., Variations in the strontium isotopic composition of seawater during the Neogene, Geology, 19, 24-27, 1991.

Hodell, D.A., and F., Woodruff, Variations in the strontium isotopic ratio of seawater during the Miocene: Stratigraphic 
and geochemical implications, Paleoceanography, 9, 405 426, 1994.

Martini, E., Standard Tertiary and Quaternary calcareous nannoplankton zonation, Proc. Plank. Conf. Roma, 2, 739 $785,1971$.

McArthur, J.M., A.R., Sahami, M.F., Thirwall, A.O., Osborn, and P.J., Hamilton, Dating phosphogenesis with Sr-isotopes: Geochim. Cosmochim. Acta, 54, 1343-1351, 1990.

Pedley, H.M., Miocene sea-floor subsidence and Later subaerial solution subsidence structures in the Maltese Islands, Proc. Geol. Ass., 85, 533-547,.1975a.

Pedley, H.M., The Oligo-Miocene sediments of the Maltese Islands, Ph.D., dissertation, Univ. of Hull, Hull, England, $1975 \mathrm{~b}$.

Pedley, H.M., and S.M., Bennett, Phosphorites, hardgrounds and syndepositional solution subsidence: A paleoenvironmental model from the Miocene of the Maltese Islands, Sediment. Geol., 45, 1-34, 1985.

Pedley, H.M., M.R., House, and B., Waugh, The Geology of Malta and Gozo, Proc. Geol. Assoc., 87, 321-341, 1976.

Raymo, M.E., The Himalayas, organic carbon burial, and climate in the Miocene, Paleoceanography, 9, 399-404, 1994.

Riggs, S., P., Stille, and D., Ames, Sr isotopic age analysis of co-occuring Miocene phosphate grain types on the North Carolina continental shelf, J. Sediment. Petrol., in press, 1996.

Roman, F., and J., Roger, Observations sur la faune de Pectinides de Malte, Bull. Soc. Géol. Fr., 5, 59-67, 1939.

Rose, E.P.F., Oligo-Miocene echinoids of the Maltese Islands, Proc. VIth Cong. Reg. Comit. Med. Neog. Stra., 1, 75-79, 1975.

Stille, P., S., Riggs, N., Clauer, D., Ames, R., Crowson, and S., Snyder, Sr and Nd isotopic analysis of phosphorite sedimentation through one Miocene high-frequency depositional cycle on the North Carolina continental shelf, Mar. Geol., 117, 253-23, 1994.
Vincent, E., and W. H., Berger, Carbon dioxide and polar cooling in the Miocene; The Monterey Hypothesis, in The Carbon Cycle and Atmospheric $\mathrm{CO}_{2}$. Natural Variations Archean to Present, Geophys. Monogr., Ser. vol. 32, edited by E.T. Sundquist and W. S. Broecker, pp.455-468, AGU, Washington, D. C., 1985.

Visser, J.P., Clay mineral stratigraphy of Miocene to Recent marine sediments in the central Mediterranean, Geol. Ultraiectina, 75, 243, 1991.

Weissert, H., C-Isotope stratigraphy, a monitor of paleoenvironmental change: A case study from the Early Cretaceous: Surv. Geophys., 10, 1-61, 1989.

Weissert, H.J., and H., Mohr, Late Jurassic Climate and its impact on carbon cycling, Palaeogeogr. Palaeoclimatol. Palaeoecol., 122, 27-43, 1996.

Woodruff, F., and S. M., Savin, Miocene deepwater oceano graphy, Paleoceanography, 4, 87-140, 1989.

Woodruff, F., and S.M., Savin, Mid-Miocene isotope stratigraphy in the deep sea: High-resolution correlations, paleoclimatic cycles, and sediment preservation, Paleoceanography, 6, 755-806, 1991.

Wright, J.D., and K.G., Miller, Miocene stable isotope stratigraphy, site 747, Kerguelen Plateau: Proc. Ocean Drill Program, Sci. Results, 120,855-866, 1992.

Zammit-Maempel, G., A new species of Coeloplerus (Echinoidea) from the Miocene of Malta, Paleontology, 12, 42-47, 1969.

E. Jacobs, G. Shields, and H. Weissert, Geological Institute, Swiss Federal Institute of Technology, CH-8092 Zürich, Switzerland.

P. Stille, CNRS, Centre de Geochemie de la Surface, F-60784, Strasbourg, France.

(Received December 29, 1995; revised July 19, 1996; accepted July 19, 1996.) 